\title{
Post-Cold War Turkish Foreign Policy in the Caspian Region within the Context of Pipeline Geopolitics and Geoeconomics
}

\author{
Gokhan Ozkan, Member, IEDRC
}

\begin{abstract}
After five Turkish Republics gained independence in Central Asia and Caucasia after the end of the Cold War, Turkish decision makers followed an active policy in the Caspian Region. In this study, post-Cold War Turkish foreign policy in the Caspian Region was analyzed within the context of natural gas and oil pipeline projects. For this aim, global and regional actors' struggle to control the critical energy infrastructure in the Caspian Region to enhance their energy security was analyzed. Natural gas and oil pipeline projects that were developed to transport hydrocarbon reserves of the Caspian Region to Europe such as Baku-Tiflis-Ceyhan, Baku-Tiflis-Erzurum, Trans-Caspian, South Stream, Nabucco and Trans-Anatolian Gas Pipeline were evaluated. Regional policies of the global and regional actors and repercussions of these policies to the Turkish foreign policy were examined. It is estimated that struggle among the regional and global actors to enhance their influence over the hydrocarbon-rich Caspian Region and over the routes that the Caspian gas and oil are transported to international markets will continue. Turkey's efforts to become an energy hub and one of the key countries of the east-west and north-south energy corridors will intensify.
\end{abstract}

Index Terms-Turkish foreign policy, Caspian region, geopolitics, geoeconomics, energy security.

\section{INTRODUCTION}

During the Cold War, Turkey had benefitted from its geostrategic location and synchronized its security and foreign policies with the West. End of the Cold War and replacement of the bipolar system with the unipolar system led to the perception that Turkey's geopolitical importance declined. Discussions about the North Atlantic Treaty Organization's (NATO) future created additional uncertainties with regards to Turkey's security policy. Turkey's geographic location in the middle of the Balkans, the Middle East, Caucasia and Central Asia and political instabilities in these regions multiplied uncertainties for Turkey.

These developments forced Turkey to revise its security and foreign policies. Turkey started to reevaluate its place and function in the international system. In this conjuncture, the newly independent Turkish Republics, Azerbaijan, Turkmenistan, Kazakhstan, Uzbekistan and Kyrgyzstan, which have linguistic, religious and cultural ties with Turkey, created excitement in Turkey. It was argued that Turkey's

Manuscript received February 17, 2014; revised April 16, 2014.

Gokhan Ozkan is with the Department of International Relations, Bursa Technical University, Bursa, Turkey (e-mail: ozkan.gkhn@gmail.com). role and influence in the region could increase. New opportunities and new challenges for the Turkish foreign policy were created as the previously closed Turkish world was opened up [1].

Pipeline projects such as the Baku-Tiflis-Ceyhan (BTC) and Trans-Caspian created opportunities for Turkey to develop its relations with the region countries [2]. The Caspian Region countries, which were looking for new political, economic and social models and which were trying to develop their relations with the West in the first half of 1990s, looked at Turkey as an attractive model and tried to develop their relations.

This rapprochement was supported by the United States (US) and the European Union (EU), which did not want the region to come once more under the influence of Russia. Energy security became one of the determining factors of "the new great game". The regional actors of "the new great game" are Turkey, Russia, Iran, China, Afghanistan and Pakistan while the global actors are the US, the EU and the Japan [3]. Blank argues that dynamics of the new great game brought the region to the brink of strategic changes [4]. The external factors that affect these changes include "well known overlapping and concurrent regional and global transformative processes like the rise of China and of India, decline of Europe, the centrality of energy and of the rivalries for access to it" [4].

Russia tried to maintain its influence in the region within the framework of its "Near Abroad (blijniye sarubiyejye)" policy after the dissolution of the Soviet Union and the establishment of the Commonwealth of Independent States (CIS). It used its control over the critical energy infrastructure over which the Caspian Region hydrocarbon resources are exported to Europe to put pressure on the region countries [5]. Meanwhile the US and the EU developed alternative pipeline routes and aimed to lower the Russian and Iranian influence in the region [6]. In this connection, geostrategic location of Turkey afforded it the opportunity to be an energy bridge between the Caspian Region and Europe.

In this paper, Turkish foreign policy in the Caspian Region will be analyzed within the context of natural gas and oil pipelines. The impact of the natural gas and oil pipeline projects on Turkey's regional policies will be evaluated. Regional and global actors' foreign policies in Central Asia and the Caucasus will be analyzed in conjunction with the Turkish foreign policy. 


\section{TURKEY'S REGIONAL POLICIES IN THE CASPIAN REGION AFTER THE END OF THE COLD WAR}

According to the Treaty of Friendship and Brotherhood signed by the Grand National Assembly of Turkey (TBMM) and the Soviet Union in 1921, Turkey and the USSR (Union of Soviet Socialist Republics) would prohibit the activities of the organizations that aimed to overthrow the governments of Turkey and the USSR. In other words, Turkey would not support Pan-Turanism in the USSR and the USSR would not support the Bolshevik organizations in Turkey [7]. After this Treaty and after Enver Pasha was killed in 1922 in Central Asia while fighting with the Russian forces, very limited contacts were made with the "Exterior Turks (Dış Türkler)" until the dissolution of the Soviet Union and the independence of the five Turkish Republics [8].

The dissolution of the Soviet Union changed global as well as regional balances fundamentally. The process of global disintegrations revealed places of high tension [9] along with the excitement of newly independent countries. In line with the Chinese proverb, great happiness and unhappiness had been born when the Soviet empire collapsed [10].

Russia and Turkey revised their roles in the international system and their regional policies in Central Asia and the Caucasus. Turkey's relations with the region countries developed very quickly after five Turkish Republics gained independence. Turkey was the first country that recognized independence of the Turkish Republics. Nonetheless, Turkey's reactive rather proactive policies in the region and its internal economic and political problems in 1990s weakened its relations with the region countries. Turkey's role as a bridge between the West and the region countries started to decline after the Western countries established direct relations with the region countries via various institutions [11].

During the first years after the collapse of the Soviet Union, Russia followed harmonious policies with the West. Nonetheless, particularly after 1993, it searched for new alternatives in the east even if it tried to maintain its good relations with the West. The struggle between the Atlantists and Eurasianists in internal politics was reflected to foreign policy debates, which had important implications for Russia's Central Asia and Caucasia policies. Russia, within the framework of its "Near Abroad" policy, declared the former Soviet Union territories as its vital sphere of influence.

Another parameter that affected Russia's regional policies was Russia's Military Doctrine adopted in November 1993. According to the Military Doctrine, the Russian armed forced would be responsible for internal security. The Doctrine allowed for the first use of nuclear weapons. It was declared that the Russian soldiers could be deployed outside the territories of the Russian Federation. Russia's "Near Abroad" policy and its Military Doctrin had important consequences for Central Asia and the Caucasus.

The Russian Federation constructed military bases in the Caspian Region and Russian soldiers started to control the borders of some countries in the region. Russia's Near Abroad policy led to confrontation between Russia and Turkey in some areas. "The Turkish World from Adriatic to the Great Wall of China" discourse pronounced first in 1992 by Süleyman Demirel, the Prime Minister of Turkey and efforts to integrate the Turkish world created negative reflections in the Russian Federation, which has millions of people of Turkish origin within its borders and which sees Central Asia and the Caucasus as its backyard.

Even if there were many contentious points between Russia and Turkey in Central Asia and the Caucasus, two countries took steps to increase cooperation in the region. "The Treaty on the Principles of Relations between the Republic of Turkey and the Russian Federation" was signed by two countries in 1992. At the joint declaration of the Turkish Prime Minister, Suleyman Demirel and the Russian President, Boris Yeltsin; two countries' common approach to the CIS countries, particularly to the Central Asian countries was emphasized and it was stated that two countries will support the economic and social development of the CIS countries.

This Treaty was significant for Central Asia and the Caucasus in many respects. First of all, it created a cooperation environment. Two countries had not defined each other as friends since the 1921 Treaty. They agreed upon supporting each other in case of an attack against any of them and decided to share their views in regional and international issues periodically. Nonetheless, it should be noted that while the Treaty was being signed, Armenia attacked Nogorno-Karabakh.

Political steps affected economic relations positively particularly with respect to the energy sector. An intergovernmental agreement between Russia and Turkey was signed in 1997. It was agreed upon that Turkey's natural gas imports that had amounted to six billion cubic meters per year would be gradually increased to 16 billion cubic meters by $2002.400 \mathrm{~km}$. long subsea pipeline, the Blue Stream, was constructed from Russia to Turkey. After this pipeline was completed, Turkey became the second biggest natural gas consumer of Russia after Germany.

There were positive and negative views about the Blue Stream Pipeline. Some argued that it was a very important project for Turkey's energy security since according to projections, Turkey would import around 75 percent of the energy it consumed by 2020 . Others argued that the Blue Stream Pipeline put obstacles in front of the projects that would transport the Turkmen gas to Turkey. It was also argued that this project would increase Turkey's dependence on Russia and would damage Turkey's relations with Turkmenistan.

The most important factors that increased the geopolitical importance of Central Asia and the Caucasus after the end of the Cold War were the rich hydrocarbon reserves of these regions and the pipelines that would transport these resources to international markets. Both Turkey and Russia initially argued that the pipelines should pass only through their territories. After it was decided that the early crude oil from Baku would be transported from the Novorossiysk Port, Turkey declared that, since the transportation of this oil would increase the traffic in the straits to dangerous levels and multiply the risk of an environmental disaster, it would adopt new regulations regarding the Straits traffic. Turkey issued two statues in 1994 and 1998.

After new natural gas and oil reserves were discovered in 
the region, competition over the pipeline routes intensified and new projects were developed. In the following sections, pipeline projects developed to transport the natural gas and oil resources of the region to international markets, energy policies of the regional and global actors and repercussions of these policies to the Turkish foreign policy will be evaluated.

\section{NATURAl GAS AND OIL PIPELINE PROJECTS IN THE CASPIAN REGION}

The Middle East and Eurasia are the most hydrocarbon-rich regions. The Middle East owns 61 percent of all the proved oil reserves in the world while the Eurasia owns 10 percent. Total share of the two regions is also striking in terms of natural gas reserves. The Middle East owns 41 percent of world's proved natural gas reserves while the Eurasia owns 30 percent. In this connection, Turkey's geographical location, which makes it both a Middle Eastern and a Eurasian country, increases its geopolitical importance.

Central Asia and Caucasia have rich natural gas and oil reserves. These regions' proximity to Russian, European and Chinese markets and the tightness of the world energy market enhance their geoeconomic and geostrategic importance [12] Struggle for exploitation and transportation of these reserves has important consequences both for international politics and the Turkish foreign policy. It is expected that, in the transformation process of the international system from a unipolar system with the US as the only superpower into a system that is shaped by dozens of actors that apply different kinds of power and that the EU, India, Russia and China are getting stronger [13]; Turkey's proximity to the natural gas and oil reserves in the Caspian Region and the Middle East and its historical and cultural ties with the region countries will strengthen Turkey's regional power status.

After the end of the Cold War, various projects were developed to transport the natural gas and oil of Central Asia and the Caucasus to international markets. In this section, these projects will be analyzed within the context of the regional and global actors' policies.

\section{A. The Baku-Tiflis-Ceyhan Pipeline, Baku-Tiflis-Erzurum Pipeline and the Trans-Caspian Pipeline Project}

The BTC Pipeline is a pipeline that transports the Caspian Region oil, particularly the Azerbaijan oil to international markets via Georgia and Turkey. Length of the BTC Pipeline is $1769 \mathrm{~km}$.; $443 \mathrm{~km}$. of which pass through the territories of Azerbaijan, $249 \mathrm{~km}$. through the territories of Georgia, and $1076 \mathrm{~km}$. through the territories of Turkey. The Pipeline's transportation capacity is 50 million barrels per year.

The BTC Pipeline, in addition to its economic contribution to Turkey, enhanced Turkey's geostrategic importance and influence in the region. The BTC Pipeline turned Turkey into an energy bridge between the Caspian Region and Europe. Turkey became one of the most important countries of the east-west energy corridor. The BTC Pipeline had been heavily criticized on the grounds that its realization was impossible. It is argued that Russia put pressure on Azerbaijan, Turkmenistan and Kazakhstan to withdraw their support for the BTC and Trans-Caspian Projects [14].

Another pipeline that increased Turkey's geopolitical importance is the Baku-Tiflis-Erzurum (BTE) Natural Gas Pipeline. The Pipeline, which is also known as South Caucasia Natural Gas Pipeline, is $970 \mathrm{~km}$. long and was constructed parallel to the BTC Pipeline. The Pipeline's capacity is 30 billion cubic meters per year. The first Shah Deniz Gas was pumped to the pipeline in March 2007. The main objective of this pipeline was to transport the Azeri natural gas to Erzurum in the first stage and to the western Turkey and the Eastern Europe in later stages. Transportation of the Kazakh and Turkmen natural gas over this pipeline is also considered.

Another project that aims to transport the hydrocarbon resources of the Caspian Region to the international markets is the Trans-Caspian Pipeline Project, which is planned to transport the Turkmen and Kazakh gas to Azerbaijan via a pipeline under the Caspian Sea and then to Turkey and Europe from Azerbaijan. In spite of the agreements signed about this project in 1998 and 1999, the project could not be realized.

Problems about the legal status of the Caspian Sea, disagreement between Turkmenistan and Azerbaijan and the 162 billion dollar energy agreement signed between Russia and Turkmenistan are seen as the main factors that prevented the realization of the Project.

\section{B. The Nabucco Project}

The Nabucco Project was a project that aimed to transport the natural gas and oil resources of Central Asia, Middle East and the Caucasus to Europe via Turkey [15]. It was supported by the US and EU since it would diminish EU's energy dependence on Russia. After the Nabucco Agreement was signed, Russian Energy Minister Sergei Shmatko cautioned against planning for an energy future without Russia in the region and reminded of an expression in Russia: "Don't sell the skin off a bear before you kill it" [16].

The EU accelerated its efforts to lower its energy dependence on Russia after the gas supplies from Russia to the EU were cut because of price disagreements between Russia and Ukraine in 2006 and 2009. In this connection, Turkey became one of the key countries for transportation of the natural gas and oil of the Caspian Region over the routes that bypass Russia. Turkey can be an energy corridor for the transportation of not only the Caspian Region but also the Middle East. The pipeline projects, while transforming Turkey into an energy hub, also increase Turkey's energy supply security.

The Nabucco Project, which was backed by the US and EU, could not be realized. It is argued that trans-Atlantic lobby could not convince the partners in the profitability of the Project, nonetheless the main problem was the scarcity of supply sources [17]. The Shah Deniz field could not even fill half of the pipeline. The Iran gas could not be included because of the opposition of the US. The EU's efforts to include the Turkmenistan gas into the project were not successful. The Turkmen gas reached China in 2009. Russia, who does not want to lose its control over the critical energy infrastructure in the Caspian Region, developed another project that would carry the region's natural resources to Europe, the South Stream Project. 


\section{The South Stream Project}

The South Stream Project, which was seen the rival project of the Nabucco Project, is evaluated as Russia's geopolitical project that aims to maintain its control over the transportation of the Caspian Region natural gas to Europe. The Project was started in 2007 by the Russian energy company Gazprom and Italian energy company Eni. In 2008, Russia and Greece signed an agreement and decided to lay the pipes, which are planned to transport natural gas from Russia to Europe via the Black Sea, Bulgaria, Greece, Serbia, Croatia, Italy and Hungary [18]. But the South Stream Project could also not be realized as of 2013.

\section{Trans-Anatolian Gas Pipeline (TANAP) Project}

TANAP Project is a project that aims to transport the Azerbaijani natural gas to Turkey and Europe. If realized, the pipeline will run from Georgia-Turkey border to the Turkey-Bulgaria border. Turkey and Azerbaijan signed Inter-Governmental Agreement on TANAP on June 2012 according to which Azerbaijani company SOCAR would hold 80 percent of shares while BOTAS and Turkish Petroleum would hold 20 percent. It is estimated that construction of the pipeline will start in 2015. The Project is estimated to cost 9 billion dollars and will be approximately $2000 \mathrm{~km}$ in length. It will transport 16 billion cubic meters of gas from Azerbaijan. The Pipeline is planned to carry the first gas to Turkey and Europe in 2018.

The TANAP project is a geostrategic project that aims to enhance energy security of Turkey and EU. Turkey and the EU will be able to diversify energy routes and sources. If realized, the TANAP Project will be the successful implementation of EU's Southern Corridor strategy.

Even if the TANAP Project will be able to transport only 16 billion cubic meters compared with 45-90 billion cubic meters of the Nabucco Project, it will still enhance the European countries' energy security by carrying gas from routes not controlled by Russia. Turkey's energy security will also be supported since Turkey is dependent on Russia and Iran at a great extent with regards to its natural gas supplies. By the realization of the Project, Turkey will be able to secure its natural gas supplies from a reliable source at a lower price. Turkey will also reach its goal to be an energy corridor that will increase its geopolitical importance significantly. The Project will also be a positive step for Turkey's relations with EU since Turkey will become one of the key countries for EU's energy security and Southern Corridor strategy. The Project will also strengthen economic and political relations among Turkey, Georgia, Azerbaijan and the EU countries.

The TANAP Project has many advantages over the Nabucco Project. First of all, there is no need to seek approval in each step from a number of players such as Bulgaria, Romania, Hungary and Austria. The Nabucco Project would have to provide gas from sources other than Azerbaijan such as Turkmenistan, Iran, Iraq and Egypt. The TANAP Project depends only on the Shah Deniz Phase Two Gas Field and will not have to deal with international, political, economic and social problems related with other countries.

Various projects were developed to transport the rich hydrocarbon resources of the Caspian Region to international markets in the east and the west. Regional and global actors struggled to realize the projects in line with their interests. In the next section, policies of regional and global actors will be analyzed. The South Stream Project, which was seen the rival project of the Nabucco Project, is evaluated as Russia's geopolitical project that aims to maintain its control over the transportation of the Caspian Region natural gas

\section{Regional Policies of the Global AND Regional ACTORS}

End of the Cold War and discovery of rich natural gas and oil reserves in Central Asia and the Caucasus made the region the focus of regional and global actors. It is argued that "the new great game" started in the region. Regional and global actors struggled to realize the pipeline projects that would transport the rich hydrocarbon reserves of Central Asia and the Caucasus to international markets via routes in line with their national interests.

\section{A. Russia}

Russia, because of its rich natural gas and oil reserves, is one of the main energy suppliers of the world. Russia, because of its geographic location, is also at a strategic position with regards to transportation of the natural gas and oil to international markets in the east and the west. It is argued that Russia became an energy superpower and will give priority to this role since it is expected that the European and Asian countries' need for the Russian natural gas and oil will continue at least until 2030 [19].

Russia wants to reestablish its global power by enhancing its control over its own energy resources and accelerated nationalization of its energy sector during 2000s [20]. Energy exports are the main instruments of Russia's global foreign and security policy [21]. Nonetheless, Russia also wants to control the routes that the Caspian Region natural gas and oil are transported to international markets. It is argued that the Russian Federation wants to enhance its influence over these hydrocarbon-rich regions and regain its superpower status by using energy diplomacy [22].

Russia, which controlled the energy production and distribution infrastructure in this geography before the dissolution of the USSR, lost its control after the collapse of the Soviet Union. Nonetheless, it is argued that Russia aims to hold its control at least over the distribution infrastructure within the framework of its "Near Abroad" policy, enhance its influence over the region countries and hold them under its sphere of influence by preventing cooperation between the region countries, the US and the EU [23]. At this point, Turkey's role is seen very important since Turkey can become an energy corridor over which the Turkmen, Uzbek, Kazakh and Azeri natural gas and oil are transported to international markets.

Energy sector constitutes 30 percent of Russia's GDP and three-fifths of its export earnings [24]. Most of the Russian state's revenues come from the natural gas and oil exports and the fees taken for the transportation of the Caspian Region countries' hydrocarbons to Europe. It is argued that transportation of the Caspian Region countries' oil and 
natural gas over the routes that bypass Russia may give serious amount of economic damage to Russia. Further than that, it is argued that if Russia loses its control over the transportation of the Caspian Region hydrocarbons, it may have to make huge investments to provide the sufficient natural gas both for its internal markets and the European market.

Because of these reasons, Russia strongly prefers transportation of the Caspian Region natural gas and oil to international markets under its control through the Russian territories. Russia bought valuable assets, renegotiated price arrangements and signed long-term agreements with Turkmenistan, Uzbekistan and Kazakhstan to leave them with less incentive to sell their gas and oil to Europe and China [25]. It is argued that Russia used Ukraine's energy dependence on Russia to carry out economic sanctions and successfully brought a friendly regime into power in Ukraine in 2010 elections [26].

The BTC, BTE, Nabucco and the TANAP have been evaluated as pipelines and projects that can damage Russia's national interests. Russia's sensitivity about these issues was clearly understood after the clashes between Russia and Georgia in the summer of 2008. It is argued that Russia's military intervention may be a strategic move to prevent the transportation of the Caspian Region hydrocarbon reserves over the routes that bypass the Russian territories in the long-term rather than just a military action [27]. It is also argued that Russia aimed to sabotage Washington's security creditability in the face of the region countries that support the US by defeating an US ally in the region [28]. Russia's Armenia policy should also be evaluated within the context of struggle for the control of the critical energy infrastructure in the region. Nonetheless, Spechler argues that Russia, a declining power economically and militarily, is losing its control over the critical energy infrastructure in the region as the Turkmenistan-Kazakhstan-Uzbekistan-China Gas Pipeline and the BTC Pipeline indicates [29]. He also argues that Russia was unable to achieve most of its strategic aims it had set for itself until it declared its 'Near Abroad' policy.

Russia developed the South Stream Project as an alternative to the Nabucco Project. This project aims to transport the natural gas and oil of the region from Russia to Europe via the Black Sea and the Balkans. Russia also tries to maintain its control over the energy pipelines to Germany by the North Stream Project. This projects aims to lower Russia's dependence on Ukraine with respect to the transportation of the natural gas to Germany. Similar to its efforts to bypass Turkey in the South Stream Project, Russia aims to bypass Ukraine by constructing a pipeline from Russia to Germany under the Baltic Sea.

\section{B. China}

Another factor that increases the geopolitical importance of the hydrocarbon-rich Caspian Region is the interest of China, economy of which grew more than eight percent on average in the last two decades and became the second largest economy of the world after the US. China's demand for energy increased rapidly because of its fast economic growth. China tried to meet its energy demand by the investments and agreements it made in different parts of the world [30]. The
Caspian Region was seen as one of the most ideal alternatives because of its geographical proximity [31]. For China, access to Caspian Region oil and gas enhances its energy security by reducing its dependence on energy resources passing through the Malacca Strait [32].

China took its first step in the region by the agreement it signed with Kazakhstan in 1997 for the Tengiz Region oil. It also developed the Central Asia Natural Gas Project, according to which the Turkmen, Uzbek, and Kazakh natural gas will be transported to China. This project was realized in 2009 and the first Turkmen gas was pumped to the pipeline and reached Beijing in 2009. China also developed the Altai Natural Gas Project with Russia. It bought the Canadian company Petro-Kazakhstan in 2005 that gives it control over $12 \%$ of Kazakh oil output, built the Atasu-Alashankou Pipeline that carries the Kazakh oil to China and concluded a production-sharing agreement for Darkhan fields in Kazakhstan [33] Tsygankov argues that while the West and Russia continue to struggle for the natural resources of the Caspian Region, China is building natural gas and oil pipelines from Turkmenistan, Kazakhstan and Uzbekistan [34].

It is argued that China's policies in the region changed after the US constructed military bases in the region after the September 11 terrorist attacks. China perceived the US military bases as indicators of the US's intention to lower China's and Russia's influence in the region and control the critical energy infrastructure besides fighting against terrorism [35]. It is argued that the Chinese authorities believe that increasing influence of the US in the region damages China's energy and national security [36].

\section{The European Union}

Energy supply security is a priority for the EU since the EU is a relatively poor region in terms of natural gas and oil reserves and has to import most of the natural gas and oil it needs. According to estimates, the EU's natural gas import will increase $87 \%$ between 2006 and 2030 because of the gap between EU gas production and consumption [37]. The EU tries to diversify the energy supplier countries and lower its energy dependence on Russia to increase its energy security. Because of this, it supports transportation of the Caspian Region natural gas and oil to Europe over routes that bypass Russia. It is argued that the main reason behind the EU's step to extend the Neighborhood Policy to the Caucasia and include Azerbaijan, Armenia and Georgia is the EU's determination to lower its dependence on Russia. It is argued that the EU's energy policy has potential to create a "clash of neighborhoods" in the region Russia defines as its "Near Abroad" [38].

Because of the EU's energy dependence on Russia, some EU countries went out of energy after the cut of natural gas supplies from Russia in 2006. A similar crisis repeated in 2009, after which the EU accelerated its steps to increase its energy security. A straightforward competition developed between Brussels and Moscow on the critical energy infrastructure of the Caspian oil and gas [39]. Nonetheless, similar kinds of obstacles the EU faced at political and military integration dimensions came in front of the EU also at the energy dimension. In spite of the decisions to follow a 
common EU energy policy, bilateral agreements the member countries signed with Russia prevented the EU from following a synchronized energy policy. It is argued that since some member countries gave priority to their national interests, the EU could not constitute a common front against Russia in terms of energy policy [40]. According to projections, Russia will still be providing around one third of the EU's energy by 2025 and this indicates that Russia will continue to be a very important player in the EU's energy policy [41].

The EU's interest in Central Asia and the Caucasus goes beyond the energy dimension. Central Asia is important for the EU not only with respect to energy supply security, but also with respect to security, politics and trade. The EU, in harmony with the US's policies, tries to integrate the Central Asian and the Caucasian countries to the western political, economic and security architecture and lower Russia's influence in the region. To develop its relations with the region countries and enhance integration, programs such as the Technical Assistance to Commonwealth of Independent States (TACIS), Transportation Corridor EuropeCaucasia-Asia (TRACECA), Interstate Oil and Gas Transportation to Europe (INOGATE), Wider Europe-New Neighborhood were developed. Additionally, the EU supports the region by the funds of the European Bank for Reconstruction and Development (EBRD). It also supports the region's cooperation with international institutions such as NATO via the Partnership for Peace (PFP) program. The EU also supported regional organizations such as the GUUAM (Georgia, Ukraine, Uzbekistan, Azerbaijan, and Moldova) and pipeline projects such as the Nabucco Project.

In the summer of 2010, the EU intensified its efforts for an agreement between Turkmenistan and Azerbaijan about the transportation of the Turkmen natural gas to Azerbaijan by a pipeline that pass under the Caspian Sea. In this way, the EU aimed the inclusion of the Turkmen gas to the Nabucco Project, which would increase its feasibility and provide a competitive edge against the rival South Stream Project. Until now, plans to build a pipeline across the Caspian Sea were prevented by the opposition of Russia and Iran.

\section{The United States}

The Caspian Region is a strategically important region for the US foreign policies because of the presence of Russia, China and Iran [42]. Controlling the critical energy infrastructure to transport the Caspian Region natural gas and oil to international markets in the west has been the focus of the US's foreign policy in the region [43]. In this connection, the US supported pipeline projects such as the BTC, BTE, Nabucco and the TANAP. It is argued that the US wants the transportation of the Caspian Region hydrocarbon reserves over routes that bypass the Russian territories, did not want participation of Iran in the Nabucco Project or in any other project and wants to cut Iran's developing political and diplomatic ties with China [44].

It is argued that the US prefers pipeline projects that would externalize Iran and transport the Turkmen, Uzbek, Kazakh, Iraqi and the Egyptian oil and natural gas over Turkey to Europe. The US's policies in the region changed after the September 11 attacks. It is argued that the US does not anymore see the region only in terms of energy policy after the September 11 attacks. The region became strategic for the US and the US seeks long-term and permanent relations with the region countries [45].

\section{E. Iran}

One of the most important actors of the "new great game" in Central Asia and the Caucasus is Iran. Iran is the second richest country in terms of natural gas reserves after Russia. It is also one of the richest countries of the world in terms of oil reserves. Since Iran has not the technological capabilities to exploit all of the oil and natural gas reserves it has, it wants to enter into partnership with foreign energy companies. Iran also tries to diversify its distribution channels to transport its oil and natural gas to the European, Chinese and the Indian markets. Nonetheless, it faces obstacles because of its tense relations with the US particularly with regards to nuclear energy issue. Iran's nuclear program is seen as the most important global and regional security problem that hindered the Iran's participation in the energy projects [46].

Iran could not participate in the Nabucco Project because of the US's political pressure. The Iran-Pakistan-India Pipeline Project faced difficulties because of the instability in Pakistan. It developed another project to overcome this problem and pass Pakistan from the sea. It also considers liquidating the natural gas and to sell it as LNG (Liquidated Natural Gas). To achieve this, Iran tries to constitute the infrastructure, construct liquidation facilities and develop a LNG fleet. Iran currently gets Turkmen gas from Korpeje-Kurt-Kui Pipeline, exports gas to Turkey and Armenia.

Even if Iran has the second richest natural gas reserves of the world, because of its insufficient technological infrastructure, it cannot benefit from these reserves efficiently. In the cold winters when the demand from Iran's internal market increases, Iran cuts gas supplies to Turkey. Iran argues that it tries to get nuclear energy to satisfy its energy needs. Iran's nuclear energy studies are met with suspicion from the western countries, which prevented Iran's participation in the Nabucco Project. These developments led to rapprochement between Iran, Russia and China. Iran took similar positions with Russia in negotiations about the determination of the legal status of the Caspian Sea. It signed a 100 billion dollar energy agreement with China, which was followed by other natural gas and oil agreements between the two countries.

\section{TURKISH Foreign POLICY In THE CASPIAN REGION}

After the end of the Cold War and the dissolution of the USSR, five Turkish Republics gained independence in the region, which created excitement in Turkey. Nonetheless, because of Turkey's insufficient economic, technological, political and military capabilities and because of Turkey's reactive rather than proactive policies; great powers such as the US, the EU, Russia, China and multinational energy companies became more influential in the region's political and economic dynamics.

The Central Asian and Caucasian countries started to follow a rational, realist foreign policy based on pragmatic 
goals rather than ideological objectives, which was called "multi-vectorism" [47]. In this context, they tried to stand at equal distance from the US, Russia and China [48]. Azerbaijan, Kazakhstan, Turkmenistan and Uzbekistan, which had not the necessary technological capabilities and financial power, tried to enter into partnerships with foreign energy companies. Azerbaijan made agreements with the consortium led by the BP with the political support of the US and Turkey [49] and realized the BTC and BTE Pipeline Projects. The signing of the Nabucco Agreement could be achieved by the political and economic support of the US, the EU, Turkey and the energy companies even if it could not be realized. Because of the obstacles in front of the Nabucco Project, Turkey developed the TANAP Project with Azerbaijan.

Turkey's regional policies were shaped according to political, economic and military conjuncture. In the 1990s, Turkey supported the Trans-Caspian Project that would transport the Turkmen and Kazakh oil and gas to Azerbaijan under the Caspian Sea. It also supported transportation of the Turkmen, Kazakh and the Azeri oil and gas to Europe over Georgia and Turkey. The BTC and BTE Pipelines were realized with the support of the US. Nonetheless, the Trans-Caspian Pipeline could not be realized because of uncertainties regarding the legal status of the Caspian Sea, because of financial and political disagreement between Turkmenistan and Azerbaijan, because of the new energy agreements Turkmenistan signed with Russia after the Blue Stream Pipeline and because of the pipeline projects to transport the Turkmen gas to China.

Because of the obstacles in front of the Trans-Caspian Pipeline, Turkey followed a new policy in the beginning of 2000s. New projects were developed to transport not only the Caspian Region natural gas, but also the Middle Eastern natural gas. In this way, it was expected that the Turkmen gas could be included in the Nabucco Project before determination of the Caspian Region's legal status by carrying it over Iran to Turkey. The US and the EU supported the Nabucco Project, but opposed the inclusion of the Iran natural gas to the Nabucco Project. After the failure of the Nabucco Project because of the reasons mentioned before, Turkey developed the TANAP Project with Azerbaijan.

Turkey, which wants to transport the Middle Eastern, Central Asian and the Caucasian oil and natural gas to Europe via Turkey and become an energy hub, also tries to be the key country of the north-south energy corridor by transporting the Russian gas and oil to Asia via the Blue Stream 2 Pipeline and the Samsun-Ceyhan Pipeline. In this way, Turkey tries to be one of the key countries of both the east-west and north-south energy corridors and increase its geopolitical importance.

\section{CONCLUSION}

After the end of the Cold War and the dissolution of the USSR, fifteen countries including five Turkish Republics gained independence, which changed Turkey's policies in the Caspian Region fundamentally. Turkey evaluated the new conjuncture in the region as an opportunity to increase its cooperation with the region countries and enhance its regional power status.

The Russian Federation's western-oriented policies in the beginning of the 1990s were perceived positively by Turkey. Nonetheless, by the end of 1993, Russia's attitude towards the region changed. Russia started to follow the "Near Abroad" policy according to which it declared Central Asia and the Caucasus as its backyard. The military doctrine in 1993 supported its new regional policy.

After Russia declared its "Near Abroad" policy and its military doctrine, struggle between the regional and global actors started over the transportation routes that the region hydrocarbon resources would be transported to Europe. It was argued that "the new great game" started in the region. The EU and the US, which did not want the region countries to enter into Russia's sphere of influence again, supported the BTC, BTE, Nabucco and TANAP Projects that aimed to transport the region's hydrocarbon reserves to Europe over the routes that bypass the Russian territories. Russia developed the South Stream Project to bypass Turkey and to maintain its control over the critical energy infrastructure in the region. Another important actor, China, developed natural gas and oil pipeline projects that aimed to transport the Caspian oil and gas to China.

It is expected that rivalry over transportation routes the Caspian Region oil and natural gas will be transported to international markets will intensify and the regional and global actors will try to realize the projects in line with their national interests. Turkey cooperates with the US and the EU and supports the projects that will transport the Azerbaijani, Turkmen and the Kazakh natural gas and oil to Europe via Georgia and Turkey. Turkey is also interested in being the key country of the north-south energy corridor. In this connection, it tries to increase its cooperation with Russia and realize the Blue Stream 2 and Samsun-Ceyhan Pipeline Projects.

\section{REFERENCES}

[1] F. S. Larrabee, "Turkey's Eurasian agenda," The Washington Quarterly, vol. 34, no. 1, pp. 103-120, 2011.

[2] N. Nassibli, "Azerbaijan's geopolitics and oil pipeline issue," Perceptions, vol. 4, no. 4, pp. 114-115, 2000.

[3] M. P. Amineh and H. Houweling, "Global energy security and its geopolitical impediments-the case of the Caspian Region," Perspectives on Global Development and Technology, vol. 6, pp. 365-388, 2007.

[4] S. Blank, "Whither the new great game in central Asia?" Journal of Eurasian Studies, vol. 3, no. 2, pp. 147-160, 2012.

[5] B. Nygren, "Putin's use of natural gas to renintegrate the CIS region," Problems of Post-Communism, vol. 55, no. 4, pp. 3-15, 2008.

[6] L. Ruseckas, "Turkey and Eurasia: Oppurtunities and risks in the caspian pipeline derby," Journal of International Affairs, vol. 54, no. 1, pp. 217-236, 2000

[7] M. Gönlübol and C. Sar, "1919-1938 yılları arasında Türk Dış Politikası," in Olaylarla Türk Dış Politikası (1919-1995), Mehmet Gönlübol, Ed. Ankara: Siyasal Kitabevi, pp. 1-9, 1996.

[8] M. Aydın, "Kafkasya ve Orta Asya'yla ilişkiler," in Türk Dış Politikası, Baskın Oran, Ed. Istanbul: İletişim Yayınları, vol. II, pp. 366-439, 2001.

[9] D. Shlapentokh, "Turkmenistan and military buildup in the Caspian Region: A small state in the post-unipolar era," Journal of Eurasian Studies, vol. 4, no. 2, pp. 154-159, 2013.

[10] Y. N. Zabortseva, "From the "forgotten region" to the "great game" region: On the development of geopolitics in central Asia," Journal of Eurasian Studies, vol. 3, no. 2, pp. 168-176, 2012.

[11] Y. E. Gürbüz, "Orta Asya'nın ortasında bir ada: Kırgızistan," Hacettepe Üniversitesi Türkiyat Araştırmaları Dergisi, no. 15, pp. 419-447, 2011. 
[12] J. A. Garrison and A. Abdurahmonov, "Explaining the central Asian energy game: complex interdependence and how small states influence their big neighbors," Asian Perspective, vol. 35, no. 3, pp. 381-405, 2011.

[13] R. N. Haass, "The age of nonpolarity - what will follow US dominance?" Foreign Affairs, vol. 87, no. 3, pp. 44-56, 2008.

[14] S. Blank, "The strategic importance of central Asia: an American view," Parameters, vol. 38, no. 1, pp. 73-87, 2008.

[15] J. M. Roberts, "The Black Sea and European energy security," Southeast European and Black Sea Studies, vol. 6, no. 2, pp. 207-223, 2006.

[16] D. Freifeld, “The great pipeline opera," Foreign Policy, pp. 120-127, September-October 2009.

[17] P. K. Baev, "From European to Eurasian energy security: Russia needs and energy perestroika," Journal of Eurasian Studies, vol. 3, no. 2, pp. 177-184, 2012.

[18] R. L. Arcas, "EU relations with China and Russia: how to approach new superpowers in trade matters," Journal of International Commercial Law and Technology, vol. 4, no. 1, pp. 22-42, 2009.

[19] S. Sevastyanov, "The more assertive and pragmatic new energy policy in Putin's Russia: security implications for northeast Asia," East Asia, no. 25, pp. 35-55, 2008.

[20] N. Poussenkova, "The global expansion of Russia's energy giants," Journal of International Affairs, vol. 63, no. 2, pp. 103-121, 2010

[21] S. Blank, "Russian energy and Russian security," The Whitehead Journal of Diplomacy and International Relations, vol. 12, no. 1, pp. 173-188, 2011

[22] E. Ismailov and V. Papava, "A new concept for the Caucasus," Southeast European and Black Sea Studies, vol. 8, no. 3, pp. 283-298, 2008.

[23] B. Shaffer, "The geopolitics of the Caucasus," Brown Journal of World Affairs, vol. 15, no. 2, pp. 131-142, 2009.

[24] C. Roberts, "Russia's BRICs diplomacy: rising outsider with dreams of an insider," Polity, vol. 42, no. 1, pp. 38-73, 2010.

[25] A.P. Tsygankov, "The Heartland no more: Russia's weakness and Eurasia's meltdown," Journal of Eurasian Studies, vol. 3, no.1, pp. 1-9, 2012.

[26] R. E. Newnham, "Pipeline politics: Russian energy sanctions and the 2010 Ukrainian elections," Journal of Eurasian Studies, vol. 4, no. 2, pp. 115-122, 2013.

[27] B. Shaffer, "The geopolitics of the Caucasus," Brown Journal of World Affairs, vol. 15, no. 2, pp. 131-142, 2009.

[28] D. Trenin, "Russia in the Caucasus: Reversing the tide," Brown Journal of World Affairs, vol. 15, no. 2, pp. 143-155, 2009.

[29] M. C. Spechler and D. R. Spechler, "Russia's lost position in central Eurasia," Journal of Eurasian Studies, vol. 4, no. 1, pp. 1-7, 2013.

[30] S. Chen, "Motivations behind China's foreign oil quest: a perspective from the Chinese government and the oil companies," Journal of Chinese Political Science, vol. 13, no. 1, pp. 79-104, 2008.

[31] X. Xu, "The oil and gas links between Central Asia and China: A geopolitical perspective," OPEC Review, pp. 33-54, March 1999.

[32] B. Womack, "China between region and world," The China Journal, no. 61, pp. 1-20, 2099.
[33] P. Kubicek, "Energy politics and geopolitical competition in the Caspian basin," Journal of Eurasian Studies, vol. 4, no. 2, pp. 171-180, 2013.

[34] A. P. Tsygankov, "Russia and the CIS in 2011," Asian Survey, vol. 52, no. 1 , pp. 42-51, 2012.

[35] R. Ong, "China's strategic convergence with Russia," Korean Journal of Defense Analysis, vol. 21, no. 3, pp. 315-328, 2009.

[36] P. K. Lee, "China's quest for oil security: Oil (wars) in the pipeline?" The Pacific Review, vol. 18, no. 2, pp. 265-301, 2005.

[37] B. Söderbergh, K. Jakobsson, and K. Aleklett, "European energy security: An analysis of future Russian natural gas production and exports," Energy Policy, vol. 38, no. 12, pp. 7827-7843, 2010.

[38] P. Flenley, "Russia and the EU: The clash of new neighbouhoods?" Journal of Contemporary European Studies, vol. 16, no. 2, pp. 189-202, 2008.

[39] S. J. Lussac, "Ensuring European energy security in Russian 'near abroad': the case of the south Caucasus," European Security, vol. 19, no. 4, pp. 607-625, 2010.

[40] A. S. Felzmann, "All for one? EU member states and the Union's common policy towards the Russian federation," Journal of Contemporary European Studies, vol. 16, no. 2, pp. 169-187, 2008.

[41] F. Holz et al., "Perspectives of the European natural gas markets until 2025," The Energy Journal, Special Issue, pp. 137-150, 2009.

[42] R. Simbar and A. G. Sheikhneshin, "Iran and Russia: strategic energy relationship," Journal of US-China Public Administration, vol. 8, no. 11. pp. 1275-1287, 2011

[43] R. N. Mcdermott, "United States and NATO military cooperation with Kazakhstan: the need for a new approach," Journal of Slavic Military Studies, no. 21, pp. 615-641, 2008.

[44] M. Ghafouri, "China's policy in the Persian Gulf," Middle East Policy, vol. 16 , no. 2 , pp. 80-92, 2009.

[45] A. M. Jaffe and R. Soligo, "Re-evaluating US strategic priorities in the Caspian region: balancing energy resource initiatives with terrorism containment," Cambridge Review of International Affairs, vol. 17, no. 2, pp. 255-268, 2004.

[46] S. Naji and J. A. Jawan, "US-iran relations in the post-cold war geopolitical order," Asian Social Science, vol. 7, no. 9, pp. 94-108, 2011.

[47] R. R. Hanks, "Multi-vector politics and Kazakhstan's emerging role as a geo-strategic player in central Asia," Journal of Balkan and Near Eastern Studies, vol. 11, no. 3, pp. 257-267, 2009.

[48] P. Stobdan, "India and Kazakhstan should share complementary objectives," Strategic Analysis, vol. 33, no. 1, pp. 1-7, 2009

[49] J. H. Kalicki, "Caspian energy at the crossroads," Foreign Affairs, vol. 80 , no. 5 , pp. $120-134,2001$

Gokhan Ozkan is an associate professor at the Department of International Relations, Faculty of Humanities and Social Sciences, Bursa Technica University. He is the author of two books and many academic papers in international journals. His areas of interest are international political economy and Turkish foreign policy. 